\title{
Article \\ Method of Mathematical Modeling for the Experimental Evaluation of Flame-Retardant Materials' Parameters
}

\author{
Dmitry Alexandrovich Korolchenko*(D) and Tatiana Yurievna Eremina \\ Department of Integrated Safety in Civil Engineering, Moscow State University of Civil Engineering, \\ Yaroslavskoye Shosse, 129337 Moscow, Russia; a.barvina@ikbs-mgsu.ru \\ * Correspondence: da-vip@mail.ru
}

\begin{abstract}
Mathematical and experimental research plays an active role in fire protection investigation The choice of optimal conditions for the experimental program is the main methodological part of this research. The peculiarities of new fire-protective compositions were investigated. Many experiments in this work are aimed at the investigation of the physical and chemical properties of the materials.
\end{abstract}

Keywords: fire retardancy; fire protection; experimental research; experimental design; mathematical methods; input and output parameters

\section{Introduction}

The variety of modern methods enables optimal planning of experiments. The investigation process is divided into several phases. In each phase, the researcher receives new data that enable them to adapt the program of experimental research. In accordance with the experimental research, the essence of the tests is in the choice of input data for the experiment. In each phase of the research, the selection of the optimal position of the points in the factor space should be made in order to obtain an optimal area for mathematical modeling. After defining the optimal zone, the task is formulated differently. Here, the investigator must understand the response surface much better, by approximating it with polynomials of the second and sometimes even third degree. Frequently the experimenter faces screening experiments, which aim to emphasize the influence of a multitude of possible effects [1-5].

Recently, due to the increase in construction volumes, as well as the construction of unique structures, the requirements for fire resistance of building structures have increased significantly. In this regard, the construction industry has shown interest in new fire-retardant coatings, as well as in steels capable of maintaining sufficient safety margins during short-term heating in fire conditions while simultaneously meeting all of the operational requirements applicable to metal structures [6-9].

The fire resistance of metal structures in fire conditions depends on many factors, principal among which are the stress-strain state, the fire intensity, and the structure's methods of fire protection. Various methods of fire protection are used to increase the fire resistance of building structures, such as concrete coating, fire-retardant cladding, fireretardant coatings, etc. The load-bearing frame of high-rise buildings is usually designed with monolithic reinforced concrete and/or steel structures, with fire protection of their structural materials, and the durability of fire protection should correspond to the design life of the building until total renovation [10-15].

The performance properties of fire-retardant coatings are directly related to the service life of the buildings, as treated steel structures are often covered with plasterboard or other materials after the fire-retardant coating is applied, and access to these coatings is permanently closed, or else rather complicated removal of wall panels is required.

Moreover, due to the fact that the service life of buildings and structures is measured in decades, there is also the issue of preserving the fire protection effect of coatings in the 
course of long-term operation. The importance of addressing this issue becomes evident when one assumes that the fire protection effect may be partially or completely lost over time, without any visible change in the coating itself.

Passive protection measures are implemented to ensure the required fire resistance rating of structures, one of them being the application of special coatings on the surface of structures, the purpose of which is to form a low-thermal-conductivity screen when heated, protecting the metal from heating and destruction [16,17].

Therefore, it is necessary to investigate the properties of flame retardants, in order to reduce their cost and improve the properties that make it possible to apply them mechanically - especially on complex structures and in hard-to-reach places-while also ensuring that they meet aesthetic requirements and do not release toxic components.

Currently, a wide range of intumescent flame retardants is used both in Russia and abroad to increase the fire resistance rating of steel structures.

A number of Russian intumescent coating studies-which raised not only the issue of creating flame retardants, but also the behavioral model of flame retardants under the effects of fire-are worth noting. Russian studies also focus on such issues as the prediction of the service life of flame-retardant coatings [18-20].

The majority of foreign studies refer to compositions that do not emit toxic gases when heated, mainly concerning compositions containing either water or inorganic fillers (e.g., vermiculite, asbestos). It should be noted that the new intumescent coatings produced on the basis of aqueous dispersions are characterized by low toxicity and low intensity of odor emissions. German researchers noted that materials containing melamine have low toxicity [21-24].

The main source of information on flame retardant studies is patent specifications. As shown by patent searches, a significant number of intumescent flame retardants based on polyvinyl acetate, acrylic styrene, and other coupling agents have been developed. Such intumescent flame retardants are applied with a thickness of approximately $1 \mathrm{~mm}$ in order to achieve a fire resistance rating of $45 \mathrm{~min}$. The intumescence of such coatings occurs in the temperature range of $200-500{ }^{\circ} \mathrm{C}$, forming a porous thermal insulating layer with an intumescence ratio of 40-60 times. The resulting thermal insulation layer has low thermal conductivity due to the formation of a cellular structure filled with low-thermalconductivity gases [25-27].

Japanese researchers offer a waterborne paint with viscosity of 50-1000 Pa.s, which contains a 100 ppm mixture ( $\mathrm{pH} 7.5-9.5$ ) consisting of (1) 2-15\% (in terms of dry residue) acrylate- or methacrylate-based copolymer (CPL) emulsion containing the C1-8 alkyl group, or CPL of said (meth)acrylates and $<30 \%$ styrene; (2) $1-5 \%$ (in terms of dry residue) dian epoxy emulsion; (3) $25-70 \%$ filler; (4) $20-60 \% \alpha$ - or $\beta$-hemihydrate plaster; (5) $1-5 \%$ color pigment; and (6) 0.8-1.2 eq. polyamine or alicyclic polyfunctional amine as a component hardener (2) and, if necessary, small amounts of other additives, the components being in the weight ratio of $[(1)+(2)] /(4)=0.15-0.28$ and $[(2)+(6)] /(1)+(2)+(5)=0.2-0.45$. The minimum component film-formation point $(1)$ is $<5^{\circ} \mathrm{C}$. The paint is used for spraycoating of construction materials. The coating provides high fire protection efficiency and durability.

The proposed flame-retardant paints and mastics are composed of the following: disperse binders, e.g., polymers and copolymers of alpha- and beta-ethylated monomers and resins (5-50\% wt.); substances charring when heated, e.g., aliphatic and alicyclic polyatomic alcohols, polysaccharides, proteins, aminoaldehyde condensates, haloid hydrocarbons, and their derivatives (4-50\%); substances emitting nonflammable gases, e.g., carbonic acid amines, cyanamide and its oligomers, and isoamides of carboxylic acids (6-50\%); charring catalysts, e.g., boric and/or phosphoric acid and their chemical compounds (3-40\%); oxygen-containing molybdenum compounds, e.g., ammonium phosphomolybdate (0.03-5.0\%), combustion inhibitors e.g., antimony and bismuth compounds (up to 12\%); and, finally, pigments, additives, and fillers to obtain the desired color and consistency. 
Nullifire Ltd. (London, UK) has developed a number of new flame retardants for building structure applications. In particular, the System-S607 material is low in toxicity, characterized by low intensity of odor emission, and is safe for handling; therefore, it can be freely used in food and other industrial plants, in apartment buildings, and in public and commercial multipurpose buildings.

Flakolight Paints (Tamil Nadu, India) is offering a new series of intumescent flameretardant paints. These paints are waterborne, non-toxic, and are capable of producing class 1 and 0 surface flame spread materials in accordance with the British Standard BS 476 parts 6 and 7 tests. Unlike most manufactured intumescent flame-retardant paints, the new series includes a special additive that extends their shelf life to two years [28-30]. The paints are available in different colors, including black, white, or transparent lacquer finishes, and can be applied using a brush or paint sprayer [31,32].

Russian authors have developed a mathematical model, algorithm, and program for thermal engineering calculation of water-containing fire retardants, allowing in particular for the recording of the effect of continuously protected surface temperature stabilization with steady increase of ambient temperature (e.g., when tested according to the standard temperature conditions) during numerous fire tests. A distinctive feature of the model is the direct consideration of the kinetics of material dehydration and moisture condensation in the intrapore space, as well as the effect of variable moisture content of the fire retardant on its thermophysical properties. This enables the developed algorithm and program to be used in the optimization of fire protection of various structures, including under actual fire conditions. The results of numerical calculations sufficiently correlate with the experimental data of both tests of simple structure fragments with fire protection on the radiant heating bench and tests of full-scale building structures in the Federal State Budgetary Establishment All-Russian Research Institute for Fire Protection of the Ministry of the Russian Federation for Civil Defence, Emergencies and Elimination of Consequences of Natural Disasters (FGBU VNIIPO EMERCOM of Russia) fired heater (FGBU VNIIPO EMERCOM of Russia, Moscow, Russia). This confirms the possibility of practical application of the developed methodology of thermotechnical calculations of water-containing fire retardants [33-38].

The properties of the intumescent flame retardants on the market differ in many aspects, such as intumescence rate, activation temperature, the moisture content of the composition in its initial state, and a number of other parameters. The nomenclature of existing intumescent flame retardants is fairly wide, and has a tendency to increase further $[39,40]$.

In accordance with GOST 12.1.044-89, polymers are materials capable of igniting when exposed to an ignition source and burning up independently after the source is removed. Polymer combustion is a complex physical and chemical process involving chemical reactions of degradation, crosslinking, and carbonization of the polymer in the condensed phase, chemical reactions of conversion and oxidation of gaseous products, and physical processes of intense heat and mass transfer. A large number of chemically diverse polymers are used for the production of intumescent flame retardants; therefore, it is relevant to study the behavior of polymers under the effect of the ignition source, and to determine the quality and quantity of the emitted toxic gases.

The creation of new fire protection agents requires solving a number of complex physicochemical issues of binders and fillers at standard ambient temperatures and humidity, and at high temperatures under fire conditions, as well as thermodynamics, solid-phase reactions, heat and mass transfer in capillary-porous bodies, and the mechanics of rigid bodies.

In addition, flame retardants must not only provide the required fire protection for the protected structure under external flame impingement, but also ensure good adhesion to the substrate material or structure, the required durability under normal operating conditions, manufacturability, and application to the protected structure [41-43]. 
Thus, in order to obtain a certain set of properties of the flame retardant, the following important parameters affecting the fire protection and performance properties must be considered:

The ratio between the binder and the pigment content largely determines the physicomechanical and protective properties of the coating. This value is usually referred to as the pigment volume concentration (PVC) value. At PVC $\sim 5 \%$, all properties undergo the most significant change-vapor permeability increases sharply and film strength decreases. This is commonly referred to as the critical PVC value, and is designated as CPVC. The CPVC value of aqueous compounds depends on the nature of the binder and the ability of latex particles to coalesce, along with the wetting properties of the pigment surface by the polymer and the shape and size of the pigment particles. If the maximum amount of pigment and/or fillers needs to be introduced, and a good latex film coating with the usual set of strength parameters (which are more frequently required in coating technology) is needed, a hydrophilic pigment and/or fillers, an adsorption-saturated binder, and a well-stabilized aqueous dispersion of pigment and fillers (paste) should be used.

The rheological properties of solutions (e.g., viscosity, plasticity) are primarily connected with the structure and chemical nature of the material [44-48]. The viscosity of coating materials is determined by internal friction between their layers when moving under the influence of external forces. The need to determine the viscosity index is due to the fact that coating materials with poorly selected viscosity are difficult to apply, and often result in coating surface defects (such as dimples and skips), leading to the loss of strength (performance) and flame-retardant properties of the coating. The application method also depends on the viscosity value, e.g., highly crosslinked coating materials are not suitable for application by dipping and pouring, because the excess paint does not drain away from the surface; they can be successfully applied by methods that provide high tensions or shear rates, such as spraying, brushing, and especially roller-coating methods. Most flame retardants are highly crosslinked due to the high content needed to impart flame-retardant properties [49].

Thus, extensive research is required in order to create a product with stable flameretardant and performance properties when creating aqueous flame retardants.

\section{Experimental Section}

A study was carried out on changes in the effectiveness of aqueous-based flame retardants for steel structures with different component content percentages [50-53].

Our experimental research was aimed at the evaluation of the reliability of fireretardant compounds under heat exposure, depending on the percentages of components in the formulation.

We considered changes in the fire-protective efficiency of coatings for steel constructions with various percentages of components in the formulations of their fire-retardant coatings.

Our results demonstrate that fire retardants for steel constructions increase their fire resistance limit up to approximately $60 \mathrm{~min}$, compared to $15 \mathrm{~min}$ for unprotected constructions at steel's critical temperature of $500-550{ }^{\circ} \mathrm{C}$. Moreover, fire-protective efficiency significantly depends on the formulation [54-57]. The best fire-protective efficiency was demonstrated by the composition of $55 \%$ liquid glass, $25 \%$ serpentinite, $5 \%$ mica, and $15 \%$ polystirol.

When increasing the liquid glass percentage up to $70 \%$ and mica up to $11 \%$, while decreasing polystirol down to $1 \%$, the fire resistance of the composition was equal to only $34 \mathrm{~min}$, i.e., almost half that of the composition with the formulation mentioned above.

Further analysis of fire-protective efficiency demonstrated its dependence on the percentages of liquid glass (optimal percentage of $60-65 \%$ ), polystirol (9-11\%), and serpentinite (12-15\%); these percentages also influence the intumescence ratio.

Studies of small structure and material models were carried out in order to determine the reliability of the developed flame retardants under heat exposure, depending on the different percentage ratios of the components included in the flame-retardant formulation. 
Our results show that the developed flame retardant enables an increase in the fire resistance rating of steel structures up to $60 \mathrm{~min}$, compared to $15 \mathrm{~min}$ for unprotected structures, at the critical temperature of steel $\left(500-550^{\circ} \mathrm{C}\right)$ (Figure 1). Earlier it was determined that the composition with the optimal mixing ratio of the components responsible for intumescence had the best flame retardant efficiency. In addition, this composition contains the optimal amount of titanium dioxide for the optimal intumescence ratio.

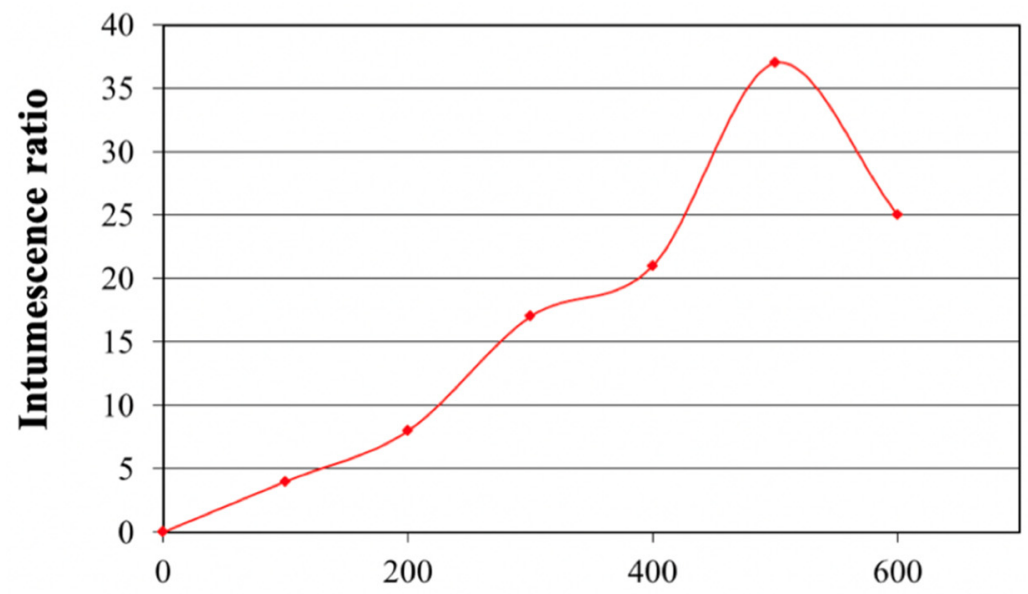

Flame retardant exposure temperature, ${ }^{\circ} \mathrm{C}$

Figure 1. Dependence of the intumescence ratio on the flame retardant exposure temperature.

Optimality means that the intumescent foam does not slip off under its weight during fire exposure, and the necessary flame retardant performance is ensured at the same time (Figure 2).

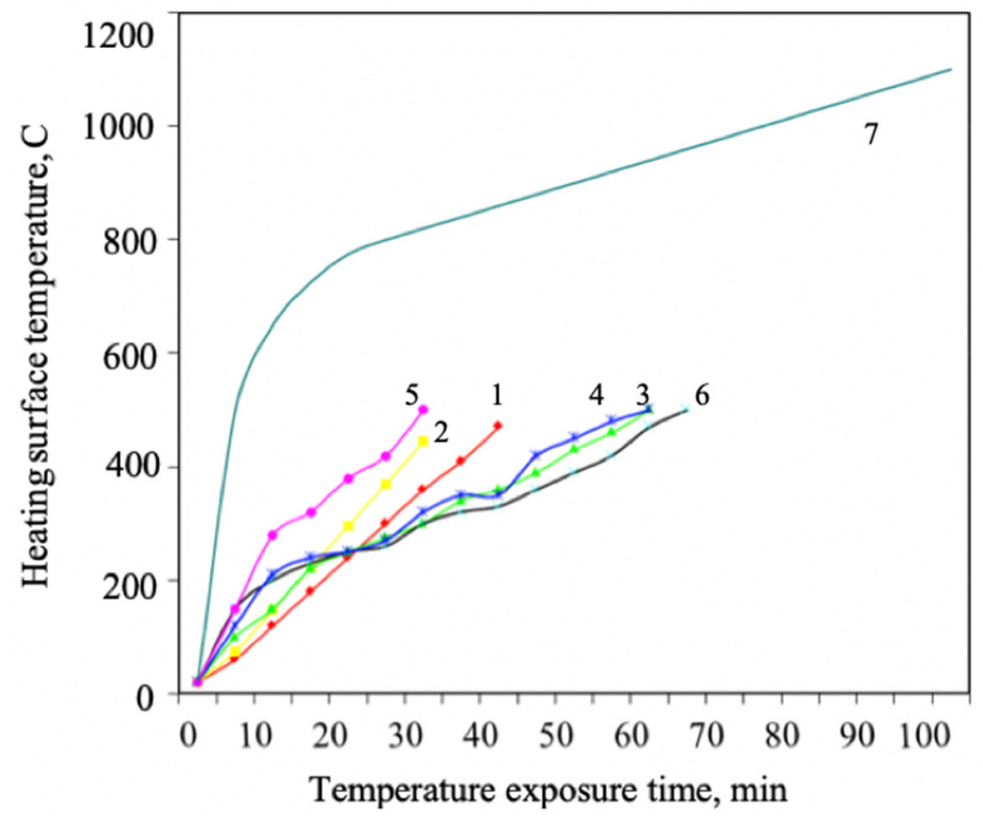

Figure 2. Changes in flame retardant efficiency depending on temperature for formulations with different component content percentages: 1-composition 1;2-composition 2; 3-composition 3; 4-composition 4; 5-composition 5; 6-composition 6; 7-standard heater temperature conditions.

The figure shows that flame retardant 3 possesses the best flame retardant efficiency. The best component content percentage is the following: phosphorus compound: intumescent 
agent: carbonizing agent $=2: 1: 1$. Results of intumescence ratio studies of coatings with different percentages of aqueous flame-retardant components are presented in Tables 1 and 2.

Table 1. Retardants and their composition (comp.).

\begin{tabular}{|c|c|c|c|c|c|c|}
\hline \multirow{2}{*}{ Component } & \multicolumn{6}{|c|}{ Percentage } \\
\hline & Comp. 1 & Comp. 2 & Comp. 3 & Comp. 4 & Comp. 5 & Comp. 6 \\
\hline Water & 19.7 & 23.8 & 20.1 & 20.1 & 16.5 & 20.1 \\
\hline Thickener & 0.4 & 0.4 & 0.4 & 0.2 & 0.2 & 0.2 \\
\hline Dispersant & 0.2 & 0.2 & 0.3 & 0.3 & 0.3 & 0.3 \\
\hline Surfactants & 0.8 & 0.6 & 0.8 & 0.8 & 0.7 & 0.8 \\
\hline Defoamer & 0.4 & 0.4 & 0.4 & 0.4 & 0.4 & 0.4 \\
\hline Coalescing agent & 1.5 & 1.5 & 1.9 & 1.9 & 1.9 & 1.9 \\
\hline Titanium dioxide & 9.0 & 6.9 & 8.3 & 8.3 & 8.3 & 8.3 \\
\hline Carbonizing agent & 6.0 & 9.6 & 12.0 & 12.0 & 11.1 & 12.0 \\
\hline Intumescent agent & 7.0 & 5.4 & 12.0 & 12.0 & 12.9 & 12.0 \\
\hline Phosphorus compound & 28.0 & 21.4 & 24.0 & 24.0 & 22.9 & 24.0 \\
\hline Polyvinyl acetate dispersion & 20.0 & 20.0 & 20.0 & 20.0 & 22.4 & - \\
\hline Chloride-containing polymer & 7.0 & 5.4 & - & - & - & - \\
\hline Acrylic dispersion & - & - & - & - & - & 20.0 \\
\hline
\end{tabular}

Table 2. Flame retardant thermogravimetric analysis results.

\begin{tabular}{|c|c|}
\hline Retardant & Thermal Effects \\
\hline Comp. 1 & $\begin{array}{l}\text { Endothermic effect in the temperature range of } 25-300^{\circ} \mathrm{C} \text {. Extreme point temperature }=223^{\circ} \mathrm{C} \text {. The maximum } \\
\text { reaction rate temperatures are } 81{ }^{\circ} \mathrm{C} \text { (water removal), } 126^{\circ} \mathrm{C} \text { (pentaerythritol decomposition), and } 223^{\circ} \mathrm{C} \text {. } \\
\text { Exothermic effect in the temperature range of } 300-418^{\circ} \mathrm{C} \text {. Extreme point temperature }=339^{\circ} \mathrm{C} \text {. Maximum } \\
\text { reaction rate temperature }=383^{\circ} \mathrm{C} \text {. } \\
\text { Exothermic effect in the temperature range of } 418-741^{\circ} \mathrm{C} \text {. Extreme point temperature }=694{ }^{\circ} \mathrm{C} \text {. The maximum } \\
\text { reaction rate temperatures are } 456,552 \text {, and } 594{ }^{\circ} \mathrm{C} \text { (full phosphorus compound decomposition). } \\
\text { Mass loss at } 418{ }^{\circ} \mathrm{C} \Delta \mathrm{m}=48.9 \% . \\
\text { Mass loss at } 601^{\circ} \mathrm{C} \Delta \mathrm{m}=82.7 \% . \\
\text { Total mass loss at } 741^{\circ} \mathrm{C} \Delta \mathrm{m}_{\text {total }}=98.6 \% .\end{array}$ \\
\hline Comp. 2 & $\begin{array}{r}\text { Endothermic effect in the temperature range of } 26-291^{\circ} \mathrm{C} \text {. Extreme point temperature }=184{ }^{\circ} \mathrm{C} \text {. The maximum } \\
\text { reaction rate temperatures are } 81 \text { (water removal), } 140,188 \text { (pentaerythritol decomposition), } 234, \text { and } 280{ }^{\circ} \mathrm{C} \\
\text { (beginning of phosphorus compound decomposition). } \\
\text { Endothermic effect in the temperature range of } 291-398^{\circ} \mathrm{C} \text {. Extreme point temperature }=328^{\circ} \mathrm{C} \text {. The maximum } \\
\text { decomposition rate temperatures are } 328 \text { and } 387^{\circ} \mathrm{C} \text { (melamine decomposition). } \\
\text { Exothermic effect in the temperature range of } 398-672{ }^{\circ} \mathrm{C} \text {. Extreme point temperatures }=450,532,577^{\circ} \mathrm{C} \text {. The } \\
\text { maximum reaction rate temperatures are } 566,601, \text { and } 642^{\circ} \mathrm{C} \text { (full phosphorus compound decomposition). } \\
\text { Mass loss at } 398^{\circ} \mathrm{C} \Delta \mathrm{m}=65.4 \% . \\
\text { Mass loss at } 601^{\circ} \mathrm{C} \Delta \mathrm{m}=84.9 \% . \\
\text { Total mass loss at } 673^{\circ} \mathrm{C}-98.2 \% .\end{array}$ \\
\hline
\end{tabular}


Table 2. Cont.

\begin{tabular}{|c|c|}
\hline Retardant & Thermal Effects \\
\hline Comp. 3 & $\begin{array}{l}\text { Endothermic effect in the temperature range of } 30-277^{\circ} \mathrm{C} \text {. Extreme point temperatures }=130 \text { and } 178^{\circ} \mathrm{C} \text {. The } \\
\text { maximum reaction rate temperatures are } 117 \text { (water removal), } 191,215,239 \text {, and } 277^{\circ} \mathrm{C} \text { (pentaerythritol } \\
\text { decomposition and beginning of phosphorus compound decomposition). } \\
\text { Endothermic effect in the temperature range of } 277-380^{\circ} \mathrm{C} \text {. Extreme point temperature }=338^{\circ} \mathrm{C} \text {. Maximum } \\
\text { reaction rate temperatures }=326,351 \text {, and } 363^{\circ} \mathrm{C} \text { (melamine decomposition). } \\
\text { Exothermic effect in the temperature range of } 380-683^{\circ} \mathrm{C} \text {. Extreme point temperature }=548^{\circ} \mathrm{C} \text {. The maximum } \\
\text { reaction rate temperatures are } 474,511,524,573 \text {, and } 671{ }^{\circ} \mathrm{C} \text { (full phosphorus compound decomposition). } \\
\text { Mass loss at } 380^{\circ} \mathrm{C} \Delta \mathrm{m}=75.0 \% . \\
\text { Mass loss at } 573^{\circ} \mathrm{C} \Delta \mathrm{m}=90.0 \% . \\
\text { Total mass loss at } 683^{\circ} \mathrm{C} \Delta \mathrm{m}_{\text {total }}=96.5 \% .\end{array}$ \\
\hline Comp. 4 & $\begin{array}{l}\text { Endothermic effect in the temperature range of } 29-292^{\circ} \mathrm{C} \text {. Extreme point temperature }=170{ }^{\circ} \mathrm{C} \text {. The maximum } \\
\text { reaction rate temperatures are } 87 \text { (water removal), } 120,146,179 \text { (surfactant, dispersant, defoamer, and coalescing } \\
\text { agent decomposition), } 248 \text {, and } 280{ }^{\circ} \mathrm{C} \text { (pentaerythritol decomposition and beginning of APP decomposition). } \\
\text { Endothermic effect in the temperature range of } 292-402{ }^{\circ} \mathrm{C} \text {. Extreme point temperature }=329^{\circ} \mathrm{C} \text {. The maximum } \\
\text { decomposition rate temperatures }=304 \text { and } 340{ }^{\circ} \mathrm{C} \text { (melamine decomposition). } \\
\text { Exothermic effect in the temperature range of } 402-902^{\circ} \mathrm{C} \text {. Extreme point temperatures }=560,759^{\circ} \mathrm{C} \text {. The } \\
\text { maximum reaction rate temperatures are } 420,438,566, \text { and } 611^{\circ} \mathrm{C} \text { (full phosphorus compound decomposition). } \\
\text { Mass loss at } 500^{\circ} \mathrm{C} \Delta \mathrm{m}=78.2 \% \text {. } \\
\text { Mass loss at } 600^{\circ} \mathrm{C} \Delta \mathrm{m}=90.4 \% \text {. Total mass loss at } 759^{\circ} \mathrm{C}=96.7 \% .\end{array}$ \\
\hline Comp. 5 & $\begin{array}{l}\text { Endothermic effect in the temperature range of } 20-314^{\circ} \mathrm{C} \text {. Extreme point temperature }=138^{\circ} \mathrm{C} \text {. The maximum } \\
\text { reaction rate temperatures are } 88^{\circ} \mathrm{C} \text { (water removal) and } 227^{\circ} \mathrm{C} \text { (pentaerythritol decomposition). } \\
\text { Endothermic effect in the temperature range of } 314-376{ }^{\circ} \mathrm{C} \text {. Extreme point temperature }=335^{\circ} \mathrm{C} \text {. The maximum } \\
\text { decomposition rate temperatures }=324 \text { and } 365^{\circ} \mathrm{C} \text { (melamine decomposition). } \\
\text { Exothermic effect in the temperature range of } 376-850{ }^{\circ} \mathrm{C} \text {. Extreme point temperature }=553^{\circ} \mathrm{C} \text {. The maximum } \\
\text { reaction rate temperatures are } 494,511,545,557, \text { and } 630{ }^{\circ} \mathrm{C} \text { (full phosphorus compound decomposition). } \\
\text { Mass loss at } 510{ }^{\circ} \mathrm{C}=75 \% . \\
\text { Mass loss at } 594{ }^{\circ} \mathrm{C}=86.6 \% . \\
\text { Mass loss at } 685^{\circ} \mathrm{C}=98.8 \% .\end{array}$ \\
\hline Comp. 6 & $\begin{array}{l}\text { Endothermic effect in the temperature range of } 31-380^{\circ} \mathrm{C} \text {. Extreme point temperatures }=134{ }^{\circ} \mathrm{C} \text { and } 335^{\circ} \mathrm{C} \text {. The } \\
\text { maximum reaction rate temperatures are } 89.9{ }^{\circ} \mathrm{C} \text { (water removal), } 235^{\circ} \mathrm{C} \text { (pentaerythritol decomposition), } 320^{\circ} \mathrm{C} \text {, } \\
335{ }^{\circ} \mathrm{C} \text {, and } 360{ }^{\circ} \mathrm{C} \text { (melamine decomposition and beginning of phosphorus compound decomposition). } \\
\text { Exothermic effect in the temperature range of } 380-690^{\circ} \mathrm{C} \text {. Extreme point temperature }=477^{\circ} \mathrm{C} \text {. The maximum } \\
\text { reaction rate temperatures are } 477^{\circ} \mathrm{C}, 490{ }^{\circ} \mathrm{C}, 530{ }^{\circ} \mathrm{C}, 547{ }^{\circ} \mathrm{C}, 592^{\circ} \mathrm{C} \text {, and } 622^{\circ} \mathrm{C} \text { (full APP decomposition). } \\
\text { Mass loss at } 407^{\circ} \mathrm{C}=68.9 \% . \\
\text { Mass loss at } 600^{\circ} \mathrm{C}=87.9 \% . \\
\text { Mass loss at } 690^{\circ} \mathrm{C}=96.6 \% .\end{array}$ \\
\hline
\end{tabular}

The main component of any flame retardant is the binder. Binders are natural and synthetic resins and other high-molecular-weight compounds capable of forming a continuous film with residual hardness, strength, and elasticity, adhesion to the substrate and the top layers of the coating, resistance to moisture, etc., on a solid substrate under certain conditions. Industrial synthetic latexes have a particle size of up to $0.25 \mu \mathrm{m}$. At $50 \%$ dry substance content, this corresponds to $1 \mathrm{~mL}$ of such latex having 1013 particles, with a specific surface area of $7.5 \mathrm{~m}^{2} / \mathrm{mL}$ (spherical particles).

The selection of a binder for a particular coating is based primarily on its performance properties. The nature of the binder determines the production technology and the basic properties of the paint coating.

Flame retardants based on polyvinyl acetate dispersions are sufficiently lightfast and weatherproof.

Flame retardants containing polyvinyl acetate dispersions can be applied over GF-021 GOST 25129-82 primer (International Scientific Innovative Center of Construction and Fire Safety, Saint-Petersburg, Russia) on almost any type of surface (metal, wood, concrete, etc.). The main properties of the most commonly used polyvinyl acetate dispersions of various grades are shown in Table 3. 
Table 3. The main grades and indicators of polyvinyl acetate dispersions available on the Russian market.

\begin{tabular}{|c|c|c|c|c|}
\hline \multirow{2}{*}{ Indicator Name } & \multicolumn{4}{|c|}{ Grade Requirements } \\
\hline & D51S & DF51/10S & DF51/10SL & DF51/15S \\
\hline 1. Dispersion appearance & \multicolumn{4}{|c|}{$\begin{array}{l}\text { White or light yellowish viscous liquid, without clumps or foreign } \\
\text { inclusions, with a particle size of } 1-3 \mu \mathrm{m} \text {. Surface film acceptable. }\end{array}$} \\
\hline $\begin{array}{l}\text { 2. Mass fraction of residual monomer (vinyl acetate), } \\
\qquad \%, \max .\end{array}$ & 0.48 & 0.48 & 0.40 & 0.48 \\
\hline $\begin{array}{l}\text { 3. Mass fraction of dry residue, } \% \text {, min. } \\
\text { (a) non-plasticized } \\
\text { (b) plasticized }\end{array}$ & 50 & $\begin{array}{l}51 \\
53\end{array}$ & $\begin{array}{l}51 \\
53\end{array}$ & $\begin{array}{l}51 \\
54\end{array}$ \\
\hline $\begin{array}{l}\text { 4. Relative viscosity in accordance with the standard } \\
\text { high-molecular-weight compound cup, s } \\
\text { (a) non-plasticized } \\
\text { (b) plasticized }\end{array}$ & $11-20$ & $\begin{array}{r}11-40 \\
11-40\end{array}$ & $\begin{array}{l}16-25 \\
16-25\end{array}$ & $\begin{array}{l}11-25 \\
16-40\end{array}$ \\
\hline 5. Hydrogen ion concentration indicator $(\mathrm{pH})$ & $4.7-6.0$ & $4.5-6.0$ & $5.0-6.0$ & $4.7-6.0$ \\
\hline $\begin{array}{l}\text { 6. Frost resistance in non-plasticized dispersion } \\
\text { freeze-thaw cycles, min. }\end{array}$ & 4 & 4 & 4 & 4 \\
\hline
\end{tabular}

Aqueous flame retardants are multicomponent and, therefore, more complex and less stable systems than the synthetic latexes used to produce them.

Aqueous flame retardants contain a number of surfactant components acting as stabilizers to prevent binder particles and pigments from sticking or sedimenting. However, immediately after the manufacture of aqueous flame retardants, processes begin to take place due to the loss of kinetic and aggregative stability of the disperse phase components, including partial coagulation of latex particles, flocculation of pigment particles and sedimentation, and biological deterioration of some organic components, leading to changes in technological characteristics (e.g., decrease in viscosity, the appearance of odor).

The goal of the formulation of an aqueous flame retardant is to select additives that provide the paint with sufficient stability and good technological properties, and that form a film with the most closed structure possible.

Dispersion film formation is understood as a process of adhesion of the dispersedphase particles when the dispersion medium is removed-for example, as a result of evaporation, with the formation of a single-phase continuous film. Based on the consideration of the laws of film formation from aqueous polymer dispersions, it is possible to formulate provisions that must be considered when selecting binders for aqueous flame retardants and conditions of coating formation. The mobility of the polymer chain at the film formation temperature has a significant (if not the decisive) influence on the film-forming ability of aqueous dispersions. Generally, latexes of polymers with $\mathrm{T}_{\mathrm{C}}$ and a minimum film-forming temperature below room temperature are used as binders for aqueous flame retardants.

Polyvinyl acetate dispersion is the most common and simple binder. This prevalence of polyvinyl acetate paints is attributed to the ease of producing aqueous polymer dispersions and the relative cheapness of the monomer, as well as the suitability of polyvinyl acetate flame retardants for both interior and exterior coatings.

The factors determining the effectiveness of flame retardants depend significantly on the chemical structure of their constituent components and the nature of the binder.

A compound demonstrates optimal properties (the lowest mass loss during combustion, high phosphorus(V) oxide content of over $72 \%$, and the lowest nitrogen content of at most $15 \%$ ) among the intumescent components available on the market of phosphorus compounds. 
The intumescence ratio and flame retardant efficiency were determined for the obtained flame retardant samples. The obtained intumescence ratio and temperature-induced mass loss results are given in Table 4.

Table 4. Dependence of intumescence ratios on phosphorus compounds from different manufacturers.

\begin{tabular}{cc}
\hline $\begin{array}{c}\text { Name of Phosphorus Compound Included in } \\
\text { the Formulation of Flame Retardant }\end{array}$ & Intumescence Ratio Indicators \\
\hline PC Exolit AP 422 & 39 \\
\hline PC Novoflam APP Alinova & 20 \\
\hline PC Novoflam APP & 32 \\
\hline PC Sample JLS-APP & 32 \\
\hline PC Sample JLS-APP 102 & 5 \\
\hline PC Sample JLS-APP SPICEAL & 4 \\
\hline PC Sample JLS-APP 103 & 28 \\
\hline PC FR CROS 484 & 39 \\
\hline PC FR CROS 282 & 7 \\
\hline PC Exflam APP-201 & 28 \\
\hline PC PHOS-CHEK P42 & 21 \\
\hline PC PHOS-CHEK P42C & 27 \\
\hline PC PHOS-CHEK P30 & 30 \\
\hline PC ANTIBLAZE & 27 \\
\hline PC Exolit AP 422 & 39 \\
\hline
\end{tabular}

Thus, the Table 4 shows that the compositions with the best intumescence ratio indicators include PC with the following indicators: mass fraction of nitrogen of no more than $15 \%$, and mass fraction of phosphorus pentoxide of $69-72 \%$. The extreme values of the aforementioned indicators were checked to confirm this hypothesis (Figure 3).

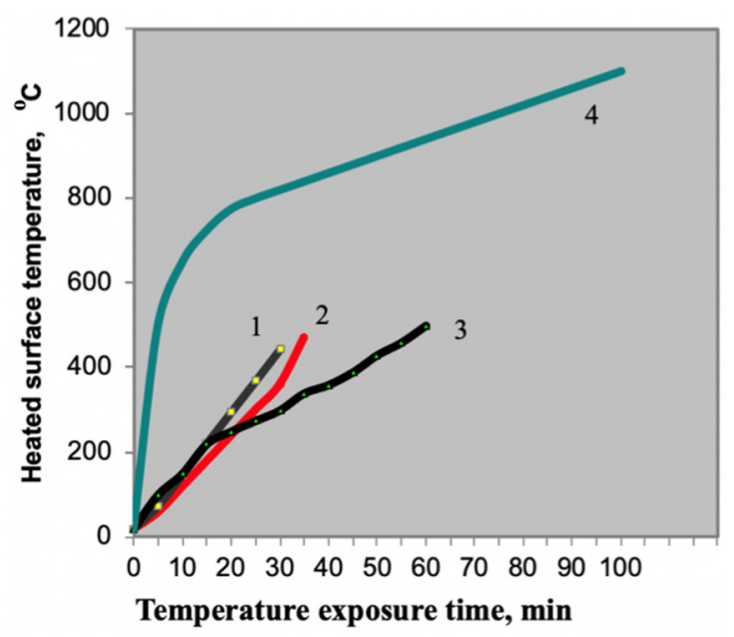

Figure 3. Flame retardant performance with the use of different phosphorus compounds: 1-PC Sample JLS-APP 102 formulation (China); 2-PC ANTIBLAZE formulation (France); 3-PC Exolit AP 422 formulation (Germany); 4-standard heater temperature conditions.

We propose a mathematical model for the optimization of fire retardant formulations (various quantitative combinations) and fire retardant properties.

The input parameters are quantitative combinations (different component content percentages) in the compound formulation, while the output parameters are the prop- 
erties (e.g., intumescence, adhesion, fire retardant efficiency). Pigments influence the intumescence ratio.

The choice of pigment is based on its properties (Table 5), including contact angle, TGA, and hydrophilicity. The film adhesive (latex film) is chosen to provide proper coverage.

Table 5. Contact angles.

\begin{tabular}{ccc}
\hline Filler Name & Contact Angle & Hydrophilicity/Hydrophobicity \\
\hline Dicyandiamide & 180 & Hydrophilic \\
\hline Melamine & 180 & Hydrophilic \\
\hline Chlorinated paraffin & $<90$ & Hydrophobic \\
\hline Diammonium phosphate & 180 & Hydrophilic \\
\hline Urea & 180 & Hydrophilic \\
\hline Phosphorus compound (Spain) & 180 & Hydrophilic \\
\hline Pentaerythritol & 180 & Hydrophilic \\
\hline Sorbitol & 180 & Hydrophilic \\
\hline Titanium dioxide & 180 & Hydrophilic \\
\hline Dipentaerythritol & 180 & Hydrophilic \\
\hline Starch & 180 & Hydrophilic \\
\hline Phosphorus compound (Germany) & 180 & Hydrophilic \\
\hline
\end{tabular}

For example, a good latex film covering can be produced within a hydrophilic pigment that stabilizes water dispersion. The pigment, in turn, influences the intumescence ratio. Therefore, we analyzed intumescent systems. Determination of hydrophilicity was reduced to the determination of the contact angles for the main fillers used in intumescent fire retardants.

For the introduction of the maximum amount of pigment and the formation of a good latex film coating with the usual set of strength parameters (which is more frequently required in coating technology), a hydrophilic pigment, an adsorption-saturated latex, and a well-stabilized aqueous pigment dispersion (paste) should be used. Further research was aimed at determining the hydrophilicity of traditional intumescent system fillers, which are divided into four groups: (a) polyols—organic hydroxyl compounds with high carbon content; (b) inorganic acids or substances that release acid at $100-250^{\circ} \mathrm{C}$; (c) organic amines or amides; and (d) halogenated compounds. The determination of hydrophilicity was reduced to determining the contact angles of the main fillers used in intumescent flame retardants. The results are presented in Table 5 .

The properties of the main components used in intumescent coatings are presented in Tables 6-9.

Table 6. Phosphate properties.

\begin{tabular}{|c|c|c|c|c|}
\hline Phosphate Name & $\begin{array}{c}\text { Water } \\
\text { Solubility }\end{array}$ & $\begin{array}{l}\text { Decomposition } \\
\text { Temperature, }{ }^{\circ} \mathrm{C}\end{array}$ & $\begin{array}{c}\text { Primary Decomposition } \\
\text { Products }\end{array}$ & $\begin{array}{c}\text { Solution (Suspension) } \\
\mathrm{pH}\end{array}$ \\
\hline $\mathrm{NH}_{4} \mathrm{H}_{2} \mathrm{PO}_{4}$ & Soluble & 147 & $\mathrm{NH}_{3}, \mathrm{H}_{3} \mathrm{PO}_{4}$ & $3-4$ \\
\hline$\left(\mathrm{NH}_{4}\right)_{2} \mathrm{HPO}_{4}$ & Soluble & 87 & $\mathrm{NH}_{3}, \mathrm{H}_{3} \mathrm{PO}_{4}$ & $8-9$ \\
\hline Urea phosphate & Soluble & 130 & $\mathrm{NH}_{3}, \mathrm{H}_{3} \mathrm{PO}_{4}, \mathrm{CO}_{2}, \mathrm{H}_{2} \mathrm{O}$ & $9-10$ \\
\hline $\begin{array}{l}\text { Ammonium } \\
\text { polyphosphate }\end{array}$ & Insoluble & 240 & $\mathrm{NH}_{3},\left(\mathrm{HPO}_{3}\right) \mathrm{n}$ & $6-7$ \\
\hline
\end{tabular}


Table 7. Foaming agent properties.

\begin{tabular}{ccccc}
\hline Foaming Agent Name & $\begin{array}{c}\text { Water } \\
\text { Solubility }\end{array}$ & $\begin{array}{c}\text { Decomposition } \\
\text { Temperature, }{ }^{\circ} \mathbf{C}\end{array}$ & $\begin{array}{c}\text { Primary Decomposition } \\
\text { Products }\end{array}$ & $\begin{array}{c}\text { Solution (Suspension) } \\
\text { pH }\end{array}$ \\
\hline Urea & Soluble & 130 & $\mathrm{NH}_{3}, \mathrm{CO}_{2}, \mathrm{H}_{2} \mathrm{O}$ & $8-9$ \\
\hline Thiourea & $\begin{array}{c}\text { Poorly } \\
\text { soluble }\end{array}$ & 96 & $\mathrm{NH}_{3}, \mathrm{CO}_{2}, \mathrm{H}_{2} \mathrm{O}, \mathrm{SO}_{2}$ & $6-7$ \\
\hline Dicyandiamide & $\begin{array}{c}\text { Poorly } \\
\text { soluble }\end{array}$ & 180 & $\mathrm{NH}_{3}, \mathrm{CO}_{2}, \mathrm{H}_{2} \mathrm{O}$ & $7-8$ \\
\hline Melamine & Insoluble & 300 & $\mathrm{NH}_{3}, \mathrm{CO}_{2}, \mathrm{H}_{2} \mathrm{O}$ & $7-8$ \\
\hline
\end{tabular}

Table 8. Carbonizing substance properties.

\begin{tabular}{cccc}
\hline $\begin{array}{c}\text { Carbonizing } \\
\text { Substance Name }\end{array}$ & Water Solubility & $\begin{array}{c}\text { Decomposition } \\
\text { Temperature, }{ }^{\circ} \mathbf{C}\end{array}$ & $\begin{array}{c}\text { Solution } \\
\text { (Suspension) } \mathbf{p H}\end{array}$ \\
\hline Starch & Soluble & 140 & 7.0 \\
\hline Sorbitol & Soluble & 110 & $6-7$ \\
\hline Pentaerythritol & Poorly soluble & 263.5 & $6-7$ \\
\hline
\end{tabular}

Table 9. Halogenated substance properties.

\begin{tabular}{cccc}
\hline $\begin{array}{c}\text { Halogenated } \\
\text { Substance Name }\end{array}$ & Water Solubility & $\begin{array}{c}\text { Decomposition } \\
\text { Temperature }\end{array}$ & $\begin{array}{c}\text { Solution } \\
\text { (Suspension) } \mathbf{p H}\end{array}$ \\
\hline $\begin{array}{c}\text { Chlorinated } \\
\text { paraffin }\end{array}$ & Insoluble & $160-350$ & $5-6$ \\
\hline $\begin{array}{c}\text { Chlorine-containing } \\
\text { polymer (KhSPEL) }\end{array}$ & Insoluble & 140 & $5-6$ \\
\hline
\end{tabular}

The experiments showed that the phosphates, foaming agents, and polyols considered in this work are hydrophilic fillers. Titanium dioxide as a pigment is also hydrophilic.

Therefore, the CPVC can be increased up to $65 \%$, but according to the reference data for polyvinyl acetate dispersions with polymeric particle size of $0.5-10 \mu \mathrm{m}$, the CPVC is $45 \%$. All intumescent flame retardants are overfilled systems; their CPVC is approximately $60 \%$, which is necessary to achieve a certain flame retardant efficiency. The developed flame retardant was tested for the whole range of physical and mechanical characteristics, and it was established that with a CPVC of $60 \%$ the strength characteristics remained high, but the water solubility increased, which only allows for the obtained flame retardant to be used indoors, or with an upper weatherproof coating.

In the process of flame retardant formulation, it was determined that the flame retardant efficiency also depends on the ratio of the components included in the intumescent system. Different ratios of components were considered: carbonizing agent: PC: foaming agent $=1: 2: 1$; carbonizing agent: PC: foaming agent $=1: 1: 1$; carbonizing agent: PC: foaming agent $=1: 2: 2$; and carbonizing agent: PC: foaming agent $=2: 2: 1$.

Further selection of components was carried out based on the stability of the resulting dispersions (Table 10). 
Table 10. Main formulations of new flame retardants.

\begin{tabular}{ccccccc}
\hline Component Description & Comp. 1 & Comp. 2 & Comp. 3 & Comp. 4 & Comp. 5 & Comp. 6 \\
\hline Water & 19.7 & 23.8 & 20.1 & 20.1 & 16.5 & 20.1 \\
\hline Carbonizing agent & 6.0 & 9.6 & 12.0 & 12.0 & 11.1 & 12.0 \\
\hline Intumescent agent & 7.0 & 5.4 & 12.0 & 12.0 & 12.9 & 12.0 \\
\hline Phosphorus compound & 28.0 & 21.4 & 24.0 & 24.0 & 22.9 & 24.0 \\
\hline Polyvinyl acetate dispersion & 20.0 & 20.0 & 20.0 & 20.0 & 22.4 & - \\
\hline Property modifier set & 19.3 & 15.3 & 11.9 & 11.9 & 11.3 & 11.9 \\
\hline
\end{tabular}

However, despite the precautions taken in the selection of components affecting the stability of the dispersions, the overall $\mathrm{pH}$ of the intumescent flame retardant was within 5-6, which made it difficult to select a thickener. Polyelectrolyte thickeners work only in an alkaline environment of $\mathrm{pH}$ up to $8-10$, so in our case it was necessary to select a thickener that would be independent of the environmental $\mathrm{pH}$, i.e., related to non-ionogenic polymers.

As a result of the study, a mathematical model was selected to determine the basic performance properties of the flame retardant.

\section{Results and Discussion}

Evaluation and prediction of fire retardant behavior (practically used or developed), with definite service time expiration, requires a set of special characteristics.

Therefore, intumescence research and coating thickness measurement are carried out on the object in order to predict fire-protective efficiency. All of the parameters mentioned above are determined by sampling the coating exactly at the object (from the material layer), where fire protection was provided, and comparing the values with those estimated in model investigation (after the research using an artificial aging method).

Coating structure changes were investigated before and after tests using the artificial aging method, based on real processing data, by sampling the coating at the object in St. Petersburg, where fire protection was provided, in order to predict the fire-protective efficiency of the composition.

Experimental research was based on mathematical modeling.

To construct a mathematical model of a complex, multifactor, multiparameter system, the following actions are required:

1. Influencing factors (IFs) $\left[\mathrm{x}_{1}, \ldots, \mathrm{x}_{\mathrm{m}}\right]$ and output parameters (OPs) $\left[\mathrm{y}_{1}, \ldots, \mathrm{y}_{\mathrm{n}}\right]$;

2. Make a plan of active multifactorial tests in the form of matrix $X$, containing $m$ columns (according to the number of IFs) and $\mathrm{N}$ rows (according to the number of tests), the main requirements for which are as follows:

(a) Lack of correlation between IFs (pair correlation coefficient $r_{\mathrm{xkl}}$ between factors $\mathrm{xk}$ and $\mathrm{xl}$ should be close to 0 );

(b) The completeness of the factor space coverage (which should be at least: $\mathrm{N}>\mathrm{m}$ );

(c) Practicability, i.e., compliance with the capabilities of the experimental bases;

(d) All experiments (combinations of IFs) in matrix $X$ are equivalent.

3. Run active tests during which IF combinations are varied according to the plan (matrix $\mathrm{X}$ ) and determine (measure) the values of the IFs, thus forming matrix Y, containing $\mathrm{N}$ rows (according to the number of tests) and $\mathrm{n}$ columns (according to the number of OPs). In this case, the results must be unambiguous, i.e., when repeating an experiment (reproducing the same IF combination), the deviation of the OP values should be insignificant;

4. Carry out mathematical processing of the active test results, which involves the following: 
(a) Determining the relationship between the OPs by calculating the OP pair correlation coefficient $\left(\mathrm{r}_{\mathrm{ykl}}\right.$ values between parameters $\mathrm{y}_{\mathrm{k}}$ and $\mathrm{y}_{\mathrm{l}}$ must be close to 0 , otherwise one of the OPs at $\mathrm{y}_{\mathrm{k}}$ or $\mathrm{y}_{1}$ can be replaced by another $\mathrm{OP}$ );

(b) Assessment of the correspondence of the sample of experimental values of each $\mathrm{j}$-th OP $\left[\mathrm{y}_{\mathrm{j} 1}, \ldots, \mathrm{y}_{\mathrm{j} N}\right]$ to normal (Gaussian) distribution, especially in accordance with the asymmetry coefficients As and kurtosis Ex (i.e., condition $\mathrm{As}=\mathrm{Ex}=0$ );

(c) Building an adequate mathematical model:

$$
\mathrm{y}_{j}=\mathrm{f}_{j}\left(x_{1}, \ldots, x_{m}\right) j I e[1, n]
$$

which in this paper will take the form of a quasilinear equation regression:

$$
\mathrm{y}_{j} \approx \sum_{k=1}^{M_{j}} a_{j k} Z_{j k}, j I e[1, n]
$$

where $a_{j k}$ is the regression coefficient, which is a component of the vector $\mathrm{A}_{j}, Z_{j k}$ is the k-th conditional factor, which is a component of the matrix $Z_{j}$, and represents the IF function $x_{1}, \ldots, x_{m}$, and $M_{j}$ is the number of regression coefficients or conditional factors $\left(M_{j}<N\right)$;

(d) Using regression Equation (1) for applied purposes:

- Interpretation of the dependence of OPs on IFs;

- Evaluating the values of OPs for combinations of IFs that differ from those included in matrix $X$;

- Assessment of the significance of the influence of IFs on OPs;

- Construction of the working area on IF sets in which each $\mathrm{j}$-th OP is within acceptable limits.

Conditional factors $\left(Z_{j k}\right)$ are selected using the accelerated choice method as part of constructing the regression Equation (2), and the vectors of the regression coefficients $\mathrm{A}_{1}, \ldots, \mathrm{A}_{\mathrm{m}}$ are calculated based on the condition of minimum variance for regression equations (least squares method):

$$
D_{\mathrm{j}}=\left(N-M_{j}\right)^{-1} \sum_{i=1}^{\mathrm{N}}\left(y_{j i}^{e}-y_{j i}^{b}\right)^{2} \rightarrow \min , \mathrm{j} I e[1, \mathrm{n}],
$$

where $y_{j i}^{e}$ and $y_{j i}^{b}$ are the values of the $\mathrm{j}$-th OP, obtained during the $\mathrm{i}$-th experiment and calculated using the regression Equation (2) for the i-th IF combination.

The adequacy of the regression Equation (2) can be assessed using the Fisher criterion.

The use of the multimodal principle, according to which the dependence of the j-th OP on the IFs can be described not by using one adequate Equation (2), but by using several such equations, also seems expedient.

It was necessary to construct a mathematical model of a complex system in the form of quasilinear regression Equation (2), containing four OPs $(n=4)$ influenced by eight IFs $(\mathrm{m}=8)$. Matrix $X$ was constructed for this specialized design of nine tests $(N=9)$.

Pre-processing of matrices $X$ and $Y$ made it possible to determine the following pair correlation coefficients (Table 11):

$$
\begin{array}{r}
r_{x 12}=r_{x 13}=r_{x 14}=r_{x 15}=r_{x 16}=r_{x 17}=r_{x 23}=r_{x 24}=r_{x 25}=r_{x 26}=r_{x 27}=r_{x 34}=r_{x 35}=r_{x 36}=r_{x 45} \\
=r_{x 46}=r_{x 47}=r_{x 56}=r_{x 57}=r_{x 67}=1,0 \\
r_{\mathrm{y} 12}=-0.276 ; r_{\mathrm{y} 13}=-0.231 ; r_{\mathrm{y} 14}=0.173 ; r_{\mathrm{y} 23}=0.703 ; r_{\mathrm{y} 24}=-0.576 ; r_{\mathrm{y} 34}=-0.841 .
\end{array}
$$


y1: expansion ratio;

y2: adhesion;

y3: durability;

y4: water resistance.

Table 11. Plan and test results of the 2nd system.

\begin{tabular}{|c|c|c|c|c|c|c|c|c|c|c|c|}
\hline \multicolumn{8}{|c|}{ Matrix X } & \multicolumn{4}{|c|}{ Matrix Y } \\
\hline$x_{1}$ & $x_{2}$ & $x_{3}$ & $x_{4}$ & $x_{5}$ & $x_{6}$ & $x_{7}$ & $x_{8}$ & $Y_{1}$ & $\mathrm{Y}_{2}$ & $\mathrm{Y}_{3}$ & $\mathrm{Y}_{4}$ \\
\hline 0.5 & 0.5 & 0.5 & 0.5 & 0.5 & 0.5 & 0.5 & 0.5 & 10 & 120 & 15 & 1 \\
\hline 1.5 & 1.5 & 0.5 & 0.5 & 1.5 & 1.5 & 0.5 & 0.5 & 10 & 48 & 15 & 1 \\
\hline 1.5 & 0.5 & 1.5 & 0.5 & 1.5 & 0.5 & 1.5 & 0.5 & 10 & 48 & 15 & 1 \\
\hline 0.5 & 1.5 & 1.5 & 0.5 & 0.5 & 1.5 & 1.5 & 1.5 & 10 & 24 & 5 & 2 \\
\hline 1.5 & 0.5 & 0.5 & 1.5 & 0.5 & 1.5 & 1.5 & 0.5 & 30 & 24 & 5 & 1 \\
\hline 0.5 & 1.5 & 0.5 & 1.5 & 1.5 & 0.5 & 1.5 & 0.5 & 30 & 24 & 3 & 2 \\
\hline 0.5 & 0.5 & 1.5 & 1.5 & 1.5 & 1.5 & 0.5 & 1.5 & 10 & 24 & 3 & 2 \\
\hline 1.5 & 1.5 & 1.5 & 1.5 & 0.5 & 0.5 & 0.5 & 0.5 & 50 & 48 & 15 & 1 \\
\hline 1.5 & 1.5 & 1.5 & 1.5 & 1.5 & 1.5 & 1.5 & 1.5 & 80 & 24 & 3 & 2 \\
\hline 15 & 30 & 16 & 16 & 7 & 3.5 & 5 & 3 & $\mathrm{As}=0.948$ & 1.57 & 0.146 & 0.187 \\
\hline 9 & 20 & 10 & 10 & 4 & 0.5 & 1.5 & 1.5 & $E x=-0.765$ & 2.24 & -2.14 & -2.17 \\
\hline
\end{tabular}

where $\mathbf{x}_{\mathbf{k i}}=0.5+\left(\mathrm{x}_{\mathrm{ki}}-\mathrm{x}_{\mathrm{kmin}}\right) /\left(\mathrm{x}_{\mathrm{kmax}}-\mathrm{x}_{\mathrm{kmin}}\right), \mathrm{k} \Theta[1.8] ; \mathrm{I} \in[1.9]$.

Four regression equations valid for the 1st $\mathrm{OP}$ were obtained in accordance with the multimodal principle:

$$
\mathrm{y}_{1 \mathrm{a}} \approx 4.622 \mathrm{z}_{1 \mathrm{a}}+5.652 \mathrm{z}_{2 \mathrm{a}}
$$

where $\mathrm{z}_{1 \mathrm{a}}=\left(\mathbf{x}_{1} \mathbf{x}_{2} \mathbf{x}_{3}\right)^{2} \mathbf{x}_{5} / \mathbf{x}_{6} ; \mathrm{z}_{2 \mathrm{a}}=\left(\mathbf{x}_{4} \mathbf{x}_{7}\right)^{2}$

$$
\mathrm{y}_{1 \mathrm{~b}} \approx 9.407 \mathrm{z}_{1 \mathrm{~b}}+6.537 \mathrm{z}_{2 \mathrm{~b}}
$$

where $\mathrm{z}_{1 \mathrm{~b}}=\mathbf{x}_{4} /\left(\mathbf{x}_{5} \mathbf{x}_{6}\right) ; \mathrm{z}_{1 \mathrm{~b}}=\mathbf{x}_{1} \mathbf{x}_{2} \mathbf{x}_{4} \mathbf{x}_{5} \mathbf{x}_{6} \mathbf{x}_{7}$

$$
\mathrm{y}_{1 \mathrm{c}} \approx 12.97 \mathrm{z}_{1 \mathrm{c}}-0.6064 \mathrm{z}_{2 \mathrm{c}}+6.019 \mathrm{z}_{3 \mathrm{c}} \text {, }
$$

where $z_{1 c}=1 ; z_{2 c}=\mathbf{x}_{3}{ }^{2} /\left(\mathbf{x}_{5}{ }^{2} \mathbf{x}_{\mathbf{6}} \mathbf{x}_{7}\right) ; z_{3 c}=\left(\mathbf{x}_{\mathbf{1}} \mathbf{x}_{\mathbf{2}} \mathbf{x}_{4}\right)^{2}$;

$$
\mathrm{y}_{1 \mathrm{~d}} \approx-4.066 \mathrm{z}_{1 \mathrm{~d}}+1.379 \mathrm{z}_{2 \mathrm{~d}}+3.892 \mathrm{z}_{3 \mathrm{~d}}+4.172 \mathrm{z}_{4 \mathrm{~d}}+1.023 \mathrm{z}_{5 \mathrm{~d}}
$$

where $z_{1 d}=x_{2}{ }^{2} \mathbf{x}_{3} x_{5} x_{6} x_{7} / x_{1} ; z_{2 d}=x_{1} x_{6} x_{7} /\left(x_{2} x_{3}{ }^{2} x_{4}\right) ; z_{3 d}=x_{1} x_{3}\left(x_{2} x_{4} x_{6}\right)^{2} / x_{7} ; z_{4 d}=x_{2} x_{3} x_{4}{ }^{2} \mathbf{x}_{7}$ $/\left(\mathbf{x}_{1}{ }^{2} \mathbf{x}_{5}{ }^{2} \mathbf{x}_{6}\right) ; z_{5 d}=\mathbf{x}_{1} \mathbf{x}_{2}{ }^{2} \mathbf{x}_{3} \mathbf{x}_{4}{ }^{2} \mathbf{x}_{5}{ }^{2} \mathbf{x}_{\mathbf{6}}$.

\begin{tabular}{|c|c|c|c|c|c|c|c|c|c|c|c|c|c|c|c|c|c|c|}
\hline No. & $y_{1}{ }^{e}$ & $\mathrm{y}_{1 \mathrm{a}}{ }^{\mathrm{c}}$ & $y_{1 c}{ }^{c}$ & $y_{1 b}{ }^{c}$ & $y_{1 d}{ }^{c}$ & $\mathrm{y}_{2}{ }^{\mathrm{e}}$ & $y_{2 a}{ }^{c}$ & $y_{2 b}{ }^{c}$ & $\mathrm{y}_{3}{ }^{\mathrm{e}}$ & $\mathrm{y}_{3 a^{c}}{ }^{c}$ & $y_{3 b}{ }^{c}$ & $y_{3 c^{c}}{ }^{c}$ & $y_{3 d}{ }^{c}$ & $\mathrm{y}_{4}{ }^{\mathrm{e}}$ & $y_{4 a^{c}}$ & $y_{4 b}{ }^{c}$ & $y_{4 c^{c}}{ }^{c}$ & $y_{4 d}{ }^{c}$ \\
\hline 1 & 10 & 0.43 & 10.6 & 18.9 & 6.84 & 1 & 1.03 & 0.997 & 15 & 15 & 15.4 & 14.7 & 15.1 & 120 & 121 & 120 & 118 & 120 \\
\hline 2 & 10 & & & & & 1 & 0.959 & & 15 & 14 & & & & & & & & 47.9 \\
\hline 3 & 10 & 20.7 & 13 & 9.03 & 7.85 & 1 & 0.983 & 0.997 & 15 & 14.7 & 14.3 & 15 & 14. & 48 & 45.6 & 53 & 49.9 & 47.9 \\
\hline 4 & 10 & 5.13 & 11.4 & & & 2 & 2 & 1.98 & 5 & & & & & 2 & & 23.3 & & 26.4 \\
\hline 5 & 30 & 28.8 & 20.3 & 27.1 & 31.2 & 1 & 1.05 & 1.0 & 5 & 4.9 & 4. & 5 & & 2 & & & & 25.5 \\
\hline 6 & 30 & 30.6 & 20.5 & 27.1 & 29.8 & 2 & 2 & 1.9 & 3 & 0.73 & 4.0 & 3.02 & & 24 & 7.7 & 22 & 19 & 23 \\
\hline 7 & 10 & & & & 10. & 2 & 2 & 2.0 & 3 & & & & & 2 & & & & 22.3 \\
\hline 8 & 60 & 55.8 & 59.7 & 59 & 60. & 1 & 0.983 & 1.0 & 15 & 14 & 15 & 14 & & 4 & & & 49.9 & 47.1 \\
\hline 9 & 80 & 81.3 & 81.2 & 80.7 & 80.1 & 2 & 2 & 1.98 & 3 & 4.94 & 3.28 & 2.87 & 3.25 & 24 & 23.8 & 27.8 & 19.3 & 24 \\
\hline$F$ & - & 15.1 & 12.7 & 46.6 & 136 & - & 277.6 & 377.7 & - & 27.1 & 65.7 & 89.3 & 97 & - & 11.6 & 27.1 & 77.1 & 384.5 \\
\hline
\end{tabular}

The experimentally obtained values of the OPs for the 2 nd system were compared with the results of calculations using the regression equations (Table 12).

Table 12. Comparison of the experimentally obtained values.

Values of the fire retardant efficiency of the material were examined for different buildings. 
The methods chosen provide formulation development and experimental research for the properties of the new aqueous intumescent fire retardant. The results of the research are quantitative values: fire retardant efficiency-45, 60, or $90 \mathrm{~min}$; intumescence ratio-20-40; heat conductivity-0.991 Wt $/ \mathrm{mK}$; film rinsability- $3.5 \mathrm{~g} / \mathrm{m}^{2}$.

A mathematical multifactorial model was developed, and the quantitative estimation of the influence of the components and their combinations on the main operating characteristics of the aqueous intumescent fire retardant was achieved.

A complex of formulations for fire retardants with stable properties was developed based on the results of the investigation of their components.

The operating properties of the materials were determined to provide fire protection.

Author Contributions: Conceptualization, D.A.K., T.Y.E.; methodology, D.A.K.; software, T.Y.E.; validation, D.A.K., T.Y.E.; formal analysis, D.A.K.; investigation, T.Y.E.; resources, D.A.K.; data curation, T.Y.E.; writing-original draft preparation, T.Y.E.; writing-review and editing, D.A.K. visualization, T.Y.E.; supervision, T.Y.E.; project administration, D.A.K.; funding acquisition, D.A.K. All authors have read and agreed to the published version of the manuscript.

Funding: This research was funded by the Ministry of Science and Higher Education of the Russian Federation (Project: Theoretical and experimental design of new composite materials to ensure safety during the operation of buildings and structures under conditions of technogenic and biogenic threats grant number \#FSWG-2020-0007).

Institutional Review Board Statement: Not applicable.

Informed Consent Statement: Informed consent was obtained from all subjects involved in the study.

Data Availability Statement: The data presented in this study are available on request from the corresponding author.

Conflicts of Interest: All authors declare no conflict of interest concerning the representation or interpretation of the reported research results.

\section{References}

1. Perez, L.; Autrique, L.; Pechoux, F. Modelling and experimental testing of intumescent coatings under high thermal flux for military applications. In Proceedings of the 11th International Symposium on Fire Safety Science, Canterbury, New Zealand, 10-14 February 2014.

2. Roberts, T.; Shirvill, L.; Waterton, W.; Buckland, I. Fire resistance of passive fire protection coatings after long-term weathering. Process. Saf. Environ. Prot. 2010, 88, 1-19. [CrossRef]

3. Eremina, T.Y.; Korolchenko, D.A.K. Fire Protection of Building Constructions with the Use of Fire-Retardant Intumescent Compositions. Buildings 2020, 10, 185. [CrossRef]

4. Oliveira, R.B.; Moreno, A.L., Jr.; Vieira, L.C. Intumescent paint as fire protection coating. Struct. Mater. J. 2017, 10, $220-231$. [CrossRef]

5. Konstantinova, N.; Eremina, T.; Kuznetsova, I. Development of fire-proof textile materials safe for human skin. Chem. Fibres 2019, 2, 54-57.

6. Akhnazarova, S.L.; Kafarov, V.V. Methods of Optimization of Experiment in Chemical Technology; Higher School: Moscow, Russia, $1985 ;$ p. 327.

7. Bartholomai, M.; Schriever, R.; Schartel, B. Influence of external heat flux and coating thickness on the thermal insulation properties of two different intumescent coatings using cone calorimeter and numerical analysis. J. Fire Mater. 2003, 27, 151-162. [CrossRef]

8. Horrocks, A.R.; Price, D. Fire Retardant Materials; Woodhead Publishing Limited: Cambridge, UK, $2001 ;$ p. 442.

9. Korolchenko, D.; Eremina, T.; Minailov, D. New Method for Quality Control of Fire Protective Coatings. In Proceedings of the IAPE '19 Conference, Oxford, UK, 14-15 March 2019.

10. Eremina, T.; Konstantinova, N.; Kuznetsova, I. Study of fireproof properties of textile materials safe when in contact with human skin. In Proceedings of the Conference Construction the Formation of Living Environment (FORM-2019), Tashkent, Uzbekistan, 18-21 April 2019.

11. Telichenko, V.I.; Roitman, V.M. Ensuring the resistance of buildings and structures under combined effects involving fire is a basic element of the integrated safety system. In Material of the 1st National Congress "Integrated Safety in Construction 2010"; IPO Publishing Ltd.: Bristol, UK, 2010; Volume 1001, pp. 15-29.

12. Roitman, V.M. Resilience of buildings and structures against progressive collapse with combined special impacts involving fire. Mosc. State Univ. Her. 2009, 2, 37-59. 
13. Roitman, V.M. Basics Fire Safety High-Rise Buildings; M. MSSU: Moscow, Russia, 2009; p. 107.

14. Nalimov, V.V. Application of Mathematical Statistics in Substance Analysis; Fizmatgiz: Moscow, Russia, $1960 ;$ p. 430.

15. Zybina, O.A.; Varlamov, A.V.; Chernova, N.S.; Mnatsakanov, S.S. On the role and transformations of components of intumescent fire-retardant paint-and-varnish formulations in the course of thermolysis. Russ. J. Appl. Chem. 2009, 82, 1542-1546. [CrossRef]

16. Bezzaponnaya, O.; Golovina, E.; Mansurov, T.; Akulov, A. The use of thermal analysis method for the comprehensive study and improvement of intumescent fire retardants. Technosphere Saf. 2017, 2, 3-7.

17. Eremina, T.; Yushko, E.; Nikolaeva, E. The influence of phosphoric acid on the reduction of crater formation of water-borne fire retardant intumescent paint. Paint. Varn. Their Use 2015, 3, 40-42.

18. Omrane, A.; Wang, Y.C.; Goransson, U.; Holmstedt, G.; Alden, M. Intumescent coating surface temperature measurement in a cone calorimeter using laser-induced phosphorescence. Fire Saf. J. 2006, 42, 68-74. [CrossRef]

19. Henderson, J.B.; Wiebelt, J.A.; Tant, M.R. A model for the thermal response of polymer composite materials with experimental verification. J. Compos. Mater. 1985, 19, 579-595. [CrossRef]

20. Shatalin, S.S.; Varlamov, A.B.; Zybina, O.A.; Mnatsakanov, S.S. About binders in fire retardant intumescent compositions. Des. Mater. Technol. 2014, 4, 37-40.

21. Garustovich, I.V.; Shishilov, O.N. Features of the Use of Fire Retardant Intumescent Coatings for Industrial Facilities [Electronic Resource]. Available online: http:/ / www.o3-e.ru/innovations/ (accessed on 1 November 2021).

22. Babkin, O.E.; Zybina, O.A.; Tanklevsky, L.T.; Mnatsakanov, S.S. Diagnostics of the application quality and efficiency of cokeforming fire-protective coatings for metal structures. Ind. Coat. 2014, 7-8, 50-54.

23. Nelson, H. Fire Severity and Fire Resistance-History of Fire Protection Engineering; National Fire Protection Association: Quincy, MA, USA, 2003

24. Yuan, J. Intumescent Coating Performance on Steel Structures under Realistic Fire Conditions. Ph.D. Thesis, School of Mechanical, Aerospace and Civil Engineering, University of Manchester, Manchester, UK, 2009.

25. Lucherini, A. Experimental Study of the Behaviour of Steel Structures Protected by Different Intumescent Coatings and Exposed to Various Fire Scenarios. Master's Thesis, Danmarks Tekniske Universitet, Kongens Lyngby, Denmark, 2016.

26. Gillet, M.; Autrique, L.; Perez, L. Mathematical model for intumescent coatings growth: Application to fire retardant systems evaluation. J. Phys. D Appl. Phys. 2007, 40, 883-899. [CrossRef]

27. Underhill, W. King's Cross Station Western Concourse. Available online: http:/ / www.architectmagazine.com (accessed on 21 May 2012).

28. Butler, K. Physical Modelling of Intumescent Fire Retardant Polymers; Building and Fire Research Laboratory, National Institute of Standards and Technology: Gaithersburg, MD, USA, 1997.

29. CMD (Construction Market Data). The Market for Fire Protection of Steel Frames Total Market (Beams and Columns) by Types of Fire Protection, Great Britain, Years 2001-2014. Available online: http:/ / www.cmdgroup.com (accessed on 28 February 2015).

30. Sorathia, U.; Gracik, T.; Ness, J.; Durkin, A.; Williams, F.; Hunstad, M.; Berry, F. Evaluation of Intumescent Coatings for Shipboard Fire Protection. J. Fire Sci. 2003, 21, 423-428. [CrossRef]

31. Kandola, B.S.; Akonda, M.H.; Horrocks, A.R. Use of highperformance fibres and intumescents as char promoters in glassreinforced polyester composites. Poly. Deg. Stab. 2005, 88, 123. [CrossRef]

32. Jimenez, M.; Duquesne, S.; Bourbigot, S. Characterization of the performance of an intumescent fire protective coating. Surf. Coat. Technol. 2006, 201, 979-987. [CrossRef]

33. Mamleev, V.S.; Bekturov, E.A.; Gibov, K.M. Dynamics of intumescence of fire-retardant polymeric materials. J. Appl. Polym. Sci. 1998, 70, 1523-1542. [CrossRef]

34. Eremina, T.Y.; Korolchenko, D.A.K.; Fadeev, V.E. Screen wall fire resistance investigation. Front. Built Environ. Indoor Environ. 2021, 6, 218. [CrossRef]

35. Wail, E.D. Fire-Protective and Flame-Retardant Coating. J. Fire Sci. 2011, 29, 259-296. [CrossRef]

36. Nalimov, V.V. Theory of Experiment. The Physico-mathematical Library of the Engineer; Nauka: Moscow, Russia, $1971 ;$ p. 208.

37. Khalturinsky, N.; Krupkin, V. On the mechanism of action of fire retardant intumescent coatings. Fire Explos. Saf. 2011, 10, 33-41.

38. Ruban, L.; Zaikov, G. Importance of intumescence in polymers fire retardancy. Int. J. Polym. Mater. 2001, 48, 295-310. [CrossRef]

39. Eremina, T. Modeling and evaluation of fire retardant efficiency of intumescent flame retardants. Buildings 2020, 10, 85.

40. Suzuki, J.; Mizukami, T.; Naruse, T.; Araki, Y. Fire Resistance of Timber Panel Structures Under Standard Fire Exposure. Fire Tech 2019, 4, 1015-1034. [CrossRef]

41. Eremina, T.; Korolchenko, D.; Kuznetsova, I. Features of Properties of the Fireproof Paint during the Operation. WMCAUS-2019. Available online: https:/ /www.wmcaus.org/files/WMCAUS2019_Book.pdf (accessed on 7 September 2020).

42. Konstantinova, N.I.; Eremina, T.Y.; Kuznetsova, I.N. Development of fireproof textile materials safe on contact with human skin. Fibre Chem. 2019, 51, 131-134. [CrossRef]

43. Eremina, T.; Gravit, M.; Dmitrieva, Y. Aspects and principles of formulation development for flame retardant intumescent compositions based on epoxy resins. Fire Explos. Saf. 2012, 7, 52-56.

44. Zybina, O.; Babkin, O. On the formulation of effective fire retardant paints and varnishes for building structures. Paint. Varn. Their Appl. 2018, 3, 44-47.

45. GOST R 53293-2009. Fire Hazard of Substances and Materials, Materials, Substances and Means. Available online: https: //runorm.com/catalog/102/828617/ (accessed on 7 September 2020). 
46. GOSTR30247.1-94. Elements of Building Constructions. Fire-Resistance Test Methods. Loadbearing and Separating Constructions. Available online: https:/ / www.russiangost.com/p-16532-gost-302471-94.aspx (accessed on 7 September 2020).

47. GOST R 30247.0-94. Elements of building Constructions. Fire-Resistance Test Methods. General Requirements. Available online: https:/ / www.russiangost.com/p-17524-gost-302470-94.aspx (accessed on 7 September 2020).

48. Zav'Yalov, D.E.; Zybina, O.A.; Mitrofanov, V.V.; Mnatsakanov, S.S. Comparative study of the behavior of ammonium phosphate in fireproofing intumescent formulations. Russ. J. Appl. Chem. 2012, 85, 1070-4272. [CrossRef]

49. Zav'yalov, D.E.; Zybina, O.A.; Chernova, N.S.; Varlamov, A.V.; Mnatsakanov, S.S. Fire intumescent compositions based on the intercalated graphite. Russ. J. Appl. Chem. 2010, 83, 1679-1682. [CrossRef]

50. Ustinov, A.; Zybina, O.; Tanklevsky, L.; Lebedev, V.; Andreev, A. Intumescent coatings with improved properties for high-rise construction. E3S Web Conf. 2018, 33, 02039. [CrossRef]

51. Ustinov, A.; Zybina, O.; Tomakhova, A.; Pavlov, S. The enhancement of operating properties of intumescent fire-protective compositions. MATEC Web Conf. 2018, 245, 11008. [CrossRef]

52. Ustinov, A.A.; Zybina, O.A.; Andreev, A.V. On the impact caused by titanium dioxide of di_erent trademarks on the properties of Intumescent fire-protective coatings. Mater. Sci. Forum 2019, 945, 212-217. [CrossRef]

53. Wang, J.Q.; Chow, W.K. A brief review on fire retardants for polymeric foams. J. Appl. Polym. Sci. 2005, 97, 366-376. [CrossRef]

54. Brodsky, V.Z. Introduction to Factor Planning of Experiment; Nauka: Moscow, Russia, 1976; p. 423.

55. Born, M.; Kun, H. The Dynamic Theory of Crystal Lattices; Foreign Literature Publishing House: Moscow, Russia, $1958 ;$ p. 488.

56. Nalimov, V.V.; Chernova, N.A. Statistical Methods for Planning Extreme Experiments; Nauka: Moscow, Russia, $1965 ;$ p. 338.

57. Markova, E.V.; Lisenkov, A.N. Combinatorial Plans in Problems of Multifactor Experiment; Nauka: Moscow, Russia, $1945 ;$ p. 345. 